\title{
A new concept of irrigation response units for effective management of surface and groundwater resources: a case study from the multi-country Fergana Valley, Central Asia
}

\author{
Usman Khalid Awan ${ }^{1} \cdot$ Mirzakhayot Ibrakhimov $^{2} \cdot$ Bogachan Benli $^{1}$ • \\ John P. A. Lamers ${ }^{3}$ - Umar Waqas Liaqat ${ }^{4}$
}

Received: 26 February 2016 / Accepted: 26 August 2016

(C) Springer-Verlag Berlin Heidelberg 2016

\begin{abstract}
When estimating canal water supplies for largescale irrigation schemes and especially in arid regions worldwide, the impact of all factors affecting the gross irrigation requirements (GIR) are not properly accounted for, which results in inefficient use of precious freshwater resources. This research shows that the concept of irrigation response units (IRU)—areas having unique combinations of factors effecting the GIR-allows for more precise estimates of GIR. An overlay analysis of soil texture and salinity, depth and salinity of groundwater, cropping patterns and irrigation methods was performed in a GIS environment, which yielded a total of 17 IRUs combinations of the Oktepa Zilol Chashmasi water consumers' association in multi-country Fergana Valley, Central Asia. Groundwater contribution, leaching requirements, losses in the irrigation system through field application and conveyance and effective rainfall were included in GIR estimates. The GIR varied significantly among IRUs [average of $851 \mathrm{~mm}( \pm 143 \mathrm{~mm})]$ with a maximum $(1051 \mathrm{~mm})$ in IRU-12 and a minimum $(629 \mathrm{~mm})$ in IRUs- 15,16 . Owing
\end{abstract}

Communicated by J. Ayars.

Usman Khalid Awan

u.k.awan@cgiar.org

1 International Center for Agricultural Research in the Dry Areas (ICARDA), Cairo, Egypt

2 Khorezm Rural Advisory Support Service (KRASS), Urgench, Uzbekistan

3 Center for Development Research (ZEF), University of Bonn, Bonn, Germany

4 Water Desalination and Reuse Center (WDRC), Division of Biological and Environmental Sciences and Engineering, King Abdullah University of Science and Technology (KAUST), Thuwal, Saudi Arabia to varying groundwater levels in each IRU, the groundwater contribution played a key role in the estimation of the GIR. The maximum groundwater contribution occurred in IRUs dominated by cotton-fallow rotations as evidenced by an average value of $159 \mathrm{~mm}$ but a maximum of $254 \mathrm{~mm}$ and a minimum of $97 \mathrm{~mm}$. Percolation losses depended on irrigation methods for different crops in their respective IRUs. The novel approach can guide water managers in this and similar regions to increase the accuracy of irrigation demands based on all the factor effecting the GIR.

\section{Introduction}

To feed the growing population, estimated to breach 9 billion by 2050 , food production needs to be virtually doubled (UNESCO 2015). This requires a judicious use of the scarce water resources and especially in the large-scale agricultural schemes constructed in the arid and semiarid regions worldwide. At present, about $18 \%$ of the agricultural land resources worldwide are under irrigation, but about $40 \%$ of the total food production stems from these resources (Postel 2001). At the same time, these irrigated areas usually are troubled by alarming levels of land salinization and waterlogging, triggered by water mismanagement. For instance, around 2.2 million ha (Mha) India's agricultural areas suffer from waterlogging and 3.47 Mha are seriously salt-affected (Tyagi 1997; Singh 2005), while about $14 \%$ of the irrigated croplands in Pakistan are heavily saline and $38 \%$ are waterlogged (Aslam and Prathapar 2006). Similar challenges exist in Egypt, Peru and other countries where irrigated agriculture is practiced.

Land degradation challenges are particularly acute in one of the world-largest irrigation and drainage schemes located in Central Asia. With the extension of the irrigated areas in 
this region from ca. 4.5 Mha in the 1960s to almost 7.9 Mha in the $1990 \mathrm{~s}$, ca. $96.3 \mathrm{~km}^{3}$ or $90 \%$ of the total annual water consumption is channeled through these irrigation schemes (Abdullaev et al. 2009). Despite often claiming lack of freshwater resources in Central Asia, water consumption for irrigated agriculture averages $10-15$ thousand $\mathrm{m}^{3} \mathrm{ha}^{-1}$ (1000$1500 \mathrm{~mm}$ ), which is considered enormous and wasted due to the low water use efficiencies (Cai et al. 2003; Varis 2014; Awan et al. 2015). The often resulting shallow groundwater levels, e.g., a few meters below surface, for instance in ca. $70 \%$ of the irrigated areas in Uzbekistan, are on the one hand a substantial source of soil moisture replenishment, but also of the ongoing soil salinization and in turn land degradation (Martius et al. 2004; Awan et al. 2011). The magnitude of capillary rise from groundwater depends on its depth and soil texture, but despite spatial and temporal variability, these factors are ill-accounted for when estimating gross irrigation requirements (GIR). This is predominantly due to the lack of tools and knowledge, which in turn results in inaccurate GIR and frequently in an improper supply of the freshwater resources. This in turn aggravates unnecessary water shortages or surplus water supplies and urgently necessitates sustainable water management practices.

In the current study, we are introducing the irrigation response units (IRU) a concept that is borrowed narrowly from the concept of hydrological response units (HRUs) recognized in the Soil and Water Assessment Tool (Arnold et al. 1998). The proposed IRU concept, however, focuses on the irrigated areas and their spatial and temporal disaggregation, which should lead to a more precise estimation of irrigation water demand. This is essential for introducing sustainable management options of surface and groundwater resources that in turn lead to higher crop yields and improved livelihoods.

This study therefore aimed at the identification of IRUs solely for the purpose of estimating the irrigation water demand for large irrigation schemes by the example of the "Oktepa Zilol Chashmasi” Water Consumers' Association (WCA) located in multi-country Fergana Valley, Central Asia. It is hoped that the results will not only be helpful for the water managers in Central Asia, but also for those in other large irrigation schemes, e.g., in Egypt, Pakistan, India, with similar agricultural production systems and facing similar challenges.

\section{Materials and methods}

\section{Research area}

The agricultural areas of the Fergana Valley are part of one of the largest irrigation schemes in Central Asia covering in total $22 \mathrm{~km}^{2}$ in the three countries Uzbekistan, Kyrgyzstan and Tajikistan (Fig. 1). Detailed data on cropping pattern, groundwater depth and salinity, and soil texture, were collected in the "Oktepa Zilol Chashmasi" WCA on the territory of Uzbekistan, with a total area of 1946 ha of which 1438 ha is irrigated (Fig. 1). The cropping portfolio is dominated by cotton and winter wheat together occupying more than $80 \%$ of the irrigated areas annually (Abdullaev et al. 2009). As such, these two crops demand most of the water resources to satisfy their irrigation demand. The average

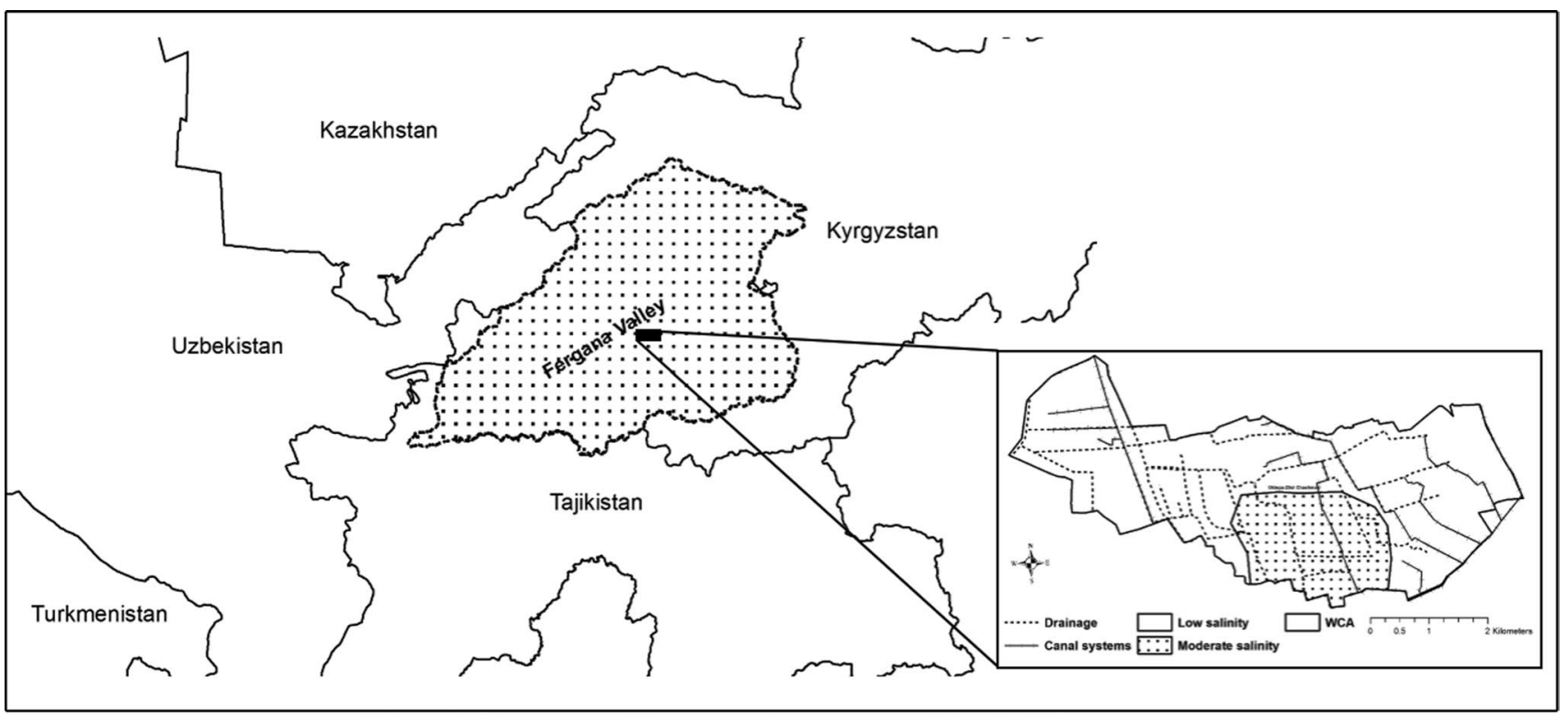

Fig. 1 Geographic location of the Fergana Valley and Oktepa Zilol Chashmasi Water Consumers' Association 

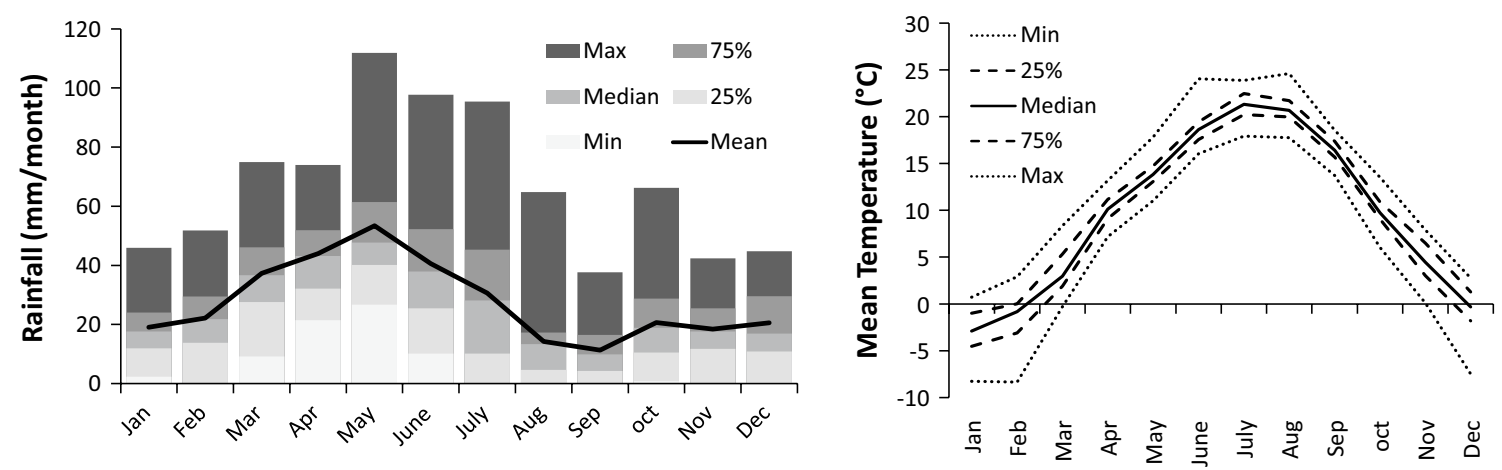

Fig. 2 Monthly rainfall and temperature patterns in the Fergana Valley, as derived from the 1972-2010 daily rainfall and temperature data

temperature in the Fergana Valley is $13.1^{\circ} \mathrm{C}$, ranging from -8 to $3{ }^{\circ} \mathrm{C}$ in January and from 17 to $36^{\circ} \mathrm{C}$ in July (Reddy et al. 2012). Due to the arid to semiarid climatic conditions with a potential ET of 1133-1294 mm, which by far prevail over precipitation (109-502 mm, Fig. 2), all crops are irrigated through surface water delivered from the Syrdarya River. According to the State Hydrogeological Amelioration Expedition of the Fergana Valley, groundwater depth is generally within $1-3 \mathrm{~m}$ below surface.

\section{Framework to establish irrigation response units}

A graphical representation of the establishment process of IRU helps in collecting details (high-resolution) and in preparing as precise as possible maps and data on factors influencing crop water demand. This in turn supports segregating the area under investigation into smaller units, but with similar biophysical conditions. The segregation was completed through Geographical Information System (GIS) software using scanned and interpolated maps of the constituent factors. These maps were overlaid and union function was used to delineate the WCA into smaller polygons having similar factors affecting the crop water requirements. The suitable minimum tolerance distance (threshold) was taken as $50 \mathrm{~m}$ to avoid a large number of polygons without compromising on real situation. Historical groundwater and soil salinity data had been collected from point measurements and interpolated over the investigated area. Soil texture and cropping patterns existed in the form of maps with a most detailed scale of 1:10,000. A described framework is presented in Fig. 3.

\section{Factors affecting irrigation water supplies}

Compulsory for the elaboration of IRU is information about all environmental factors influencing irrigation water accessibility on field level. In the subsequent subsections, the description of the influence of each factor on crop water requirements is followed by the data sources.

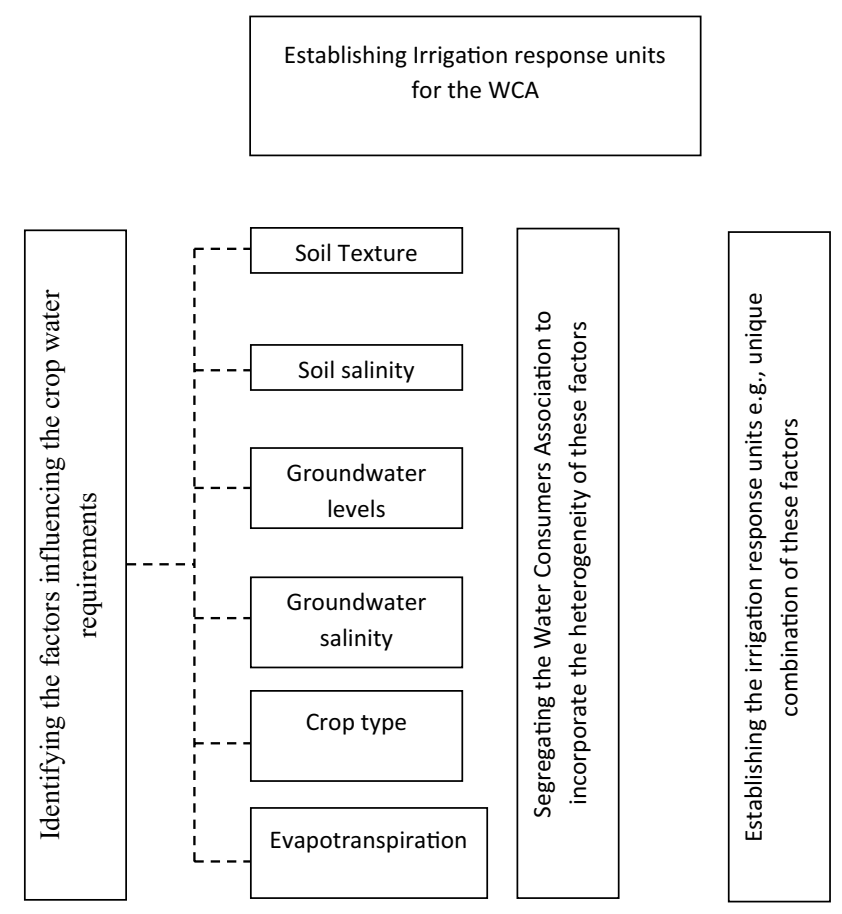

Fig. 3 Framework to establishing irrigation response units for an irrigation scheme

Soil texture Soil texture influences groundwater contribution through capillary rise from groundwater and water losses in the fields (Scanlon et al. 2006). Eventually, groundwater contribution will reduce the need for surface water supplies. In areas with permanent shallow groundwater levels, the contribution of groundwater to soil moisture in the root zone of agricultural crops can be significant and continuous (Chen and $\mathrm{Hu}$ 2004). Fine-textured soils have higher capillary rise and hence evaporation rates; consequently, with increasing distance from the surface, the soil water content will gradually decrease the upper limit of the capillary rise (Hillel 2000; Wösten et al. 2001). Accumulation of salts within the root zone is highly influenced by both the evaporation 
Fig. 4 Soil texture distribution in the Oktepa Zilol Chashmasi Water Consumers' Association in the Fergana Valley

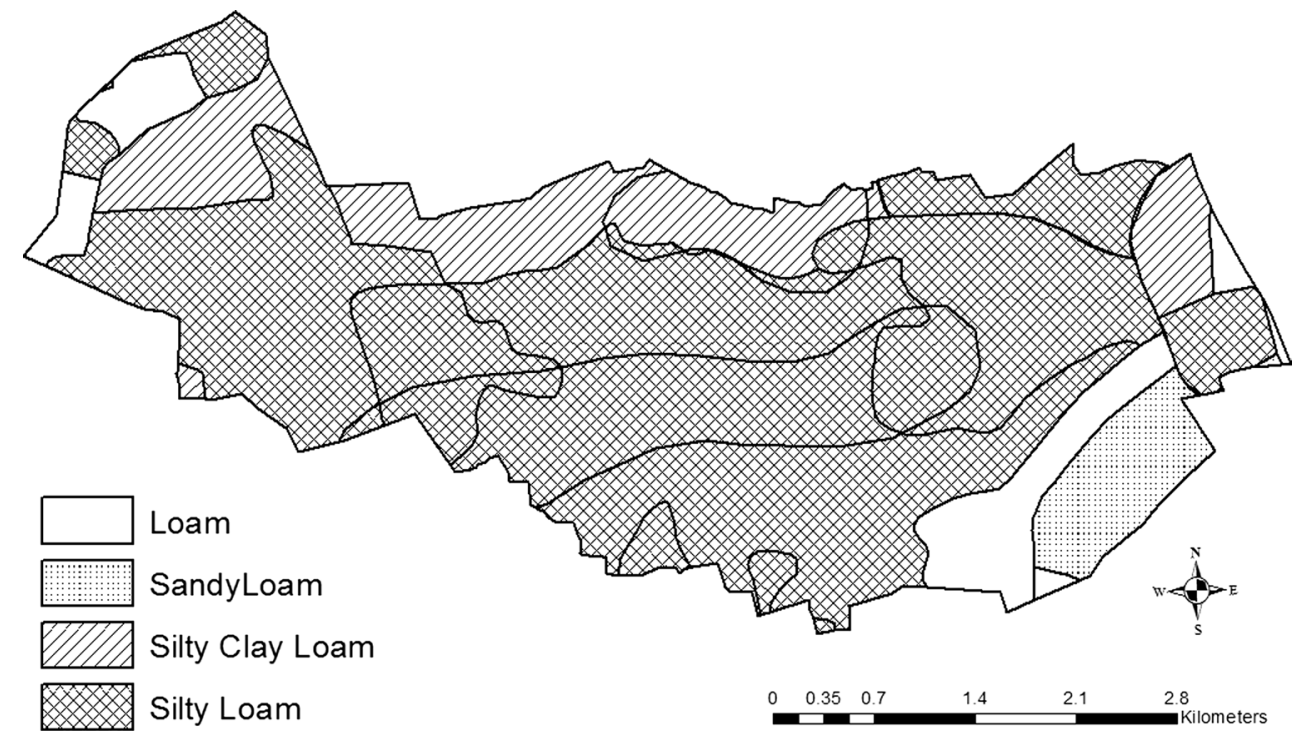

demand and the height of capillary rise, which in turn are controlled by soil texture, layers of differently textured soils, and groundwater depth and salinity (Li et al. 2012).

The soil texture map of the WCA was provided by the Cadastre Centre, Uzbekistan, digitized and visualized in ArcGIS. It consists of the three more or less distinct textural classes: silty loam, loam and sandy loam soils (Fig. 4). The largest portion encompasses silty loam soils occupying ca. $70 \%$ of the eastern and central parts of the WCA, followed by loam and sandy loam soils (Fig. 4).

Groundwater level and salinity Information on groundwater levels and salinity is essential in estimating groundwater contribution to crop water requirements (Ibrakhimov et al. 2011). Shallow groundwater contributing to soil moisture reduces total surface water demands. On the other hand, evaporation, which drives water and salts upward, extends hence the impact of groundwater within the root zone (Shah et al. 2007). The soil near the groundwater becomes saturated and with rising groundwater levels, the capillary front, dependent on soil texture, will rise sometimes even to the soil surface (Lehmann et al. 2008, Shokri and Salvucci 2011). Shallow groundwater can evaporate at a relatively high rate, which leaves the salts in the top soil (Nulsen 1981; Rasheed et al. 1989; Jalili et al. 2011). When facing an intense upward water flow, the risk of salinization at the soil surface will increase, even with low salt contents in groundwater or without saline layers in the profile. The evaporation capillary front describes the textural influence on soil water and salt dynamics and may vary widely in soils with different texture and hence hydraulic properties (Wilson 1990; Shokri and Salvucci 2011). Frequently, such contributions of groundwater to soil moisture supply are neglected (Chen and $\mathrm{Hu} 2004$ ) or accounted for only statically, without spatiotemporal variations.
Point groundwater level data were provided by the governmental Hydrogeological Melioration Expedition of the Fergana province department of Agriculture and Water Resources Management. The data were collected over 11 monitoring wells (thus, each monitoring well represents ca. 125 ha) over the period of 17 years (1998-2014) (Fig. 6). The groundwater levels were segregated into shallow (with a range of 130-160 cm) and deep (below $180 \mathrm{~cm}$ ) classes (Fig. 5). The majority of the areas assessed in ArcGIS appeared to be deep (Fig. 6), mainly located in the eastern and central parts of the WCA.

Groundwater salinity data were obtained from the same monitoring wells thrice a year in April (to assess the quality of leaching conducted in prior months), July (to analyze salt movement in groundwater due to intensive irrigations) and October (period after intensive irrigations). The groundwater salinity data were analyzed for total dissolved solids (which can be converted into EC values according to Rhoades and Kandiah Mashali 1992) and chloride ions. According to Ayers and Westcott (1985), the average groundwater salinity levels in Oktipa WCA ranged from low saline $\left(1.56 \mathrm{dS} \mathrm{m}^{-1}\right)$ (slight to moderate) to high saline (severe) $\left(3.81 \mathrm{dS} \mathrm{m}^{-1}\right.$ ) (Fig. 7). The areal distribution of higher and lower groundwater salinity levels is shown in Fig. 8.

Cropping pattern Different crops have different evapotranspiration demand in time and hence use different water amounts for their transpiration during a certain growing period (Ali 2010; Liaqat et al. 2015). Therefore, crops exert a direct effect on total water requirement due to difference in growth pattern and duration of crop development. Crop factors influencing crop water demand include types and varieties, growing stage, leaf area and types, and length and density of the roots. 


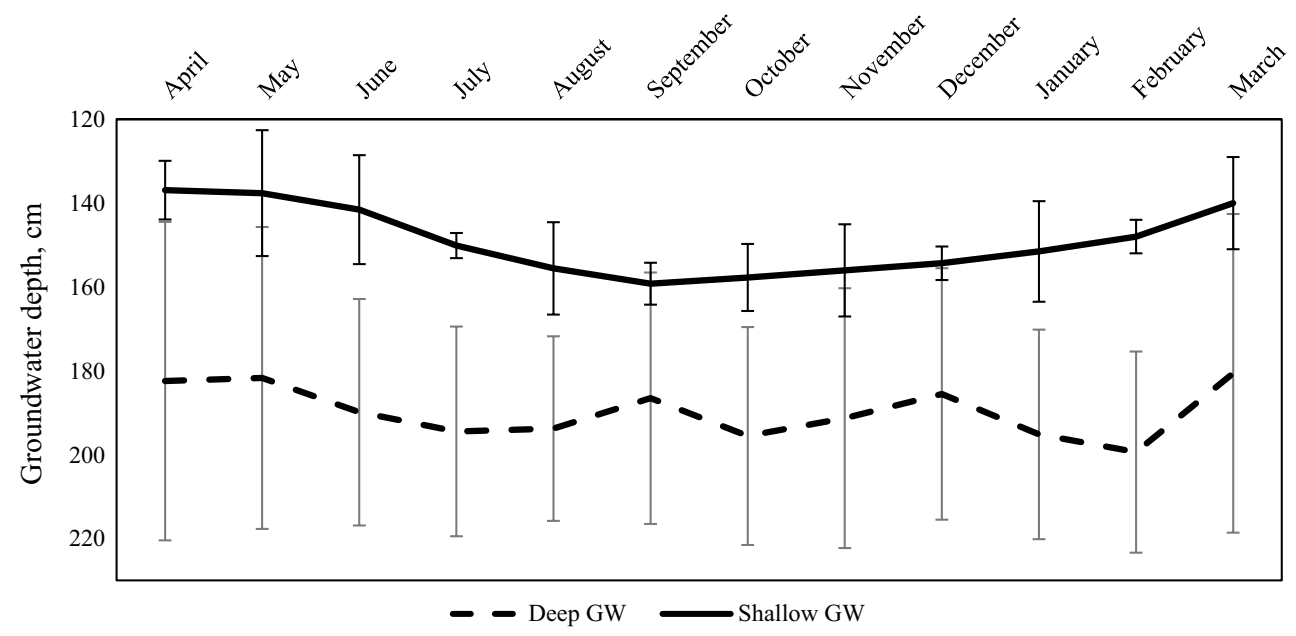

Fig. 5 Average monthly variation of shallow and deep groundwater levels in the Oktepa Zilol Chashmasi WCA, Fergana Valley. The observation wells falling into shallow ( 7 wells, ranging from 130 to
$160 \mathrm{~cm}$ depth below soil surface) and deep (4 wells, $>180 \mathrm{~cm}$ below soil surface) categories of groundwater levels are shown in Fig. 6

Fig. 6 Segregated areas with shallow (ranging from 130 to $160 \mathrm{~cm}$ below soil surface) and deep ( $>180 \mathrm{~cm}$ below soil surface) categories of groundwater levels in the Oktepa Zilol Chashmasi WCA, Fergana Valley. The observation well numbers (OW) (e.g., OW-162) shown in the figure are the official identification tags assigned to each OW by the Hydrogeological Melioration Expedition

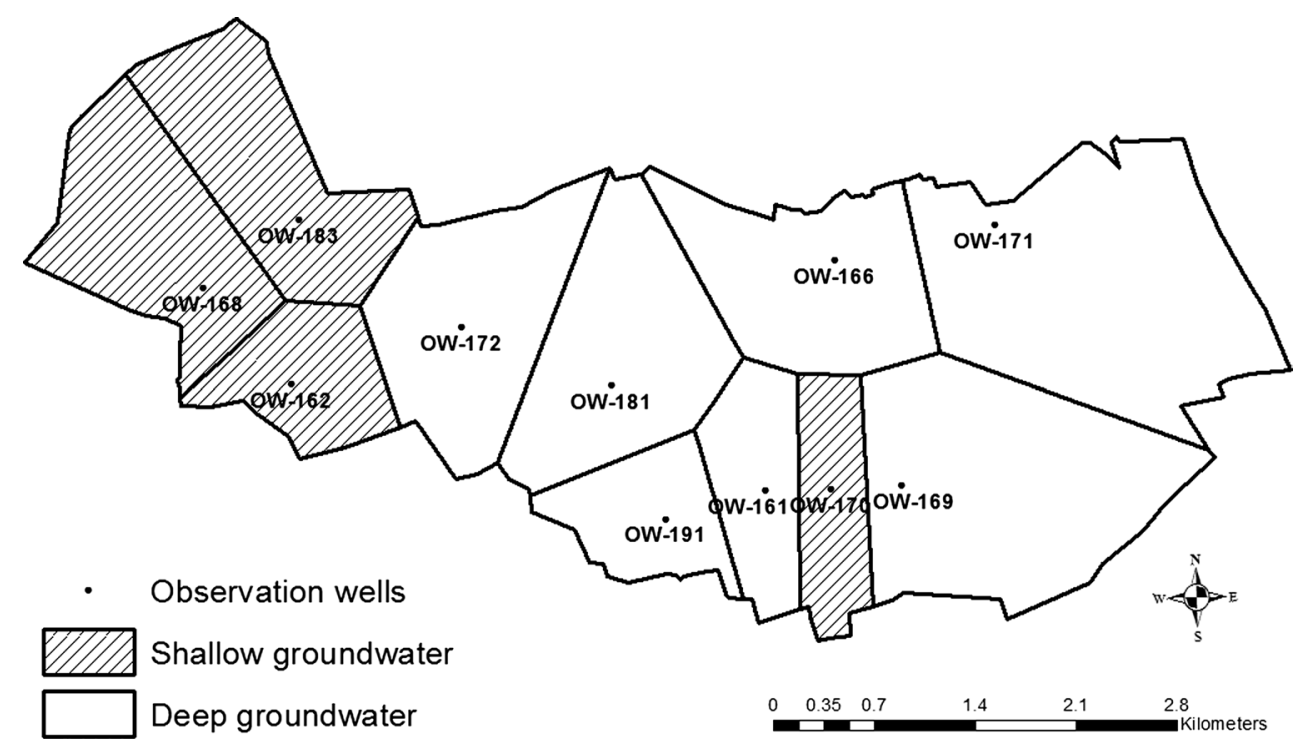

Due to the state quota for crop production in Uzbekistan, the cropping pattern in the Oktepa Zilol Chashmasi WCA was similar over the years since obtaining independence in 1991 (Fig. 9). Cotton and wheat occupied ca. $80 \%$ of the irrigated areas, and the rest of the agricultural land was cultivated by vegetables and orchards.

Soil salinity In areas with shallow saline groundwater levels and fine-textured soils, the salinization hazard tends to be elevated. The salts in soil or water reduce water availability to crops in turn affecting yields. The more crop growth is affected by salinity, the lower the evapotranspiration and the higher the leaching fraction of the applied irrigation water. Leaching is one of the most widespread means to cope with soil salinity.
According to the official data, in 2010 the area with saline soils amounted to 1159 ha $(85 \%$ of the irrigated area), including 100 ha of moderately saline and 1059 ha of slightly saline areas. The soil salinization was related to the topographic features of the area as well on depth and salinity of the groundwater. The soil salinity is routinely estimated by the staff of the Hydrogeological Melioration Expedition (OGME) from the depths 0-30, 30-70 and 70-100 $\mathrm{cm}$ once a year in October (a period beyond irrigations except for winter wheat fields) from 83 representative locations covering the entire WCA. The staff collects the soil samples from specified depths and locations and delivers these samples to the provincial level laboratory of $O G M E$ for soil salinity analyses. The moderately 


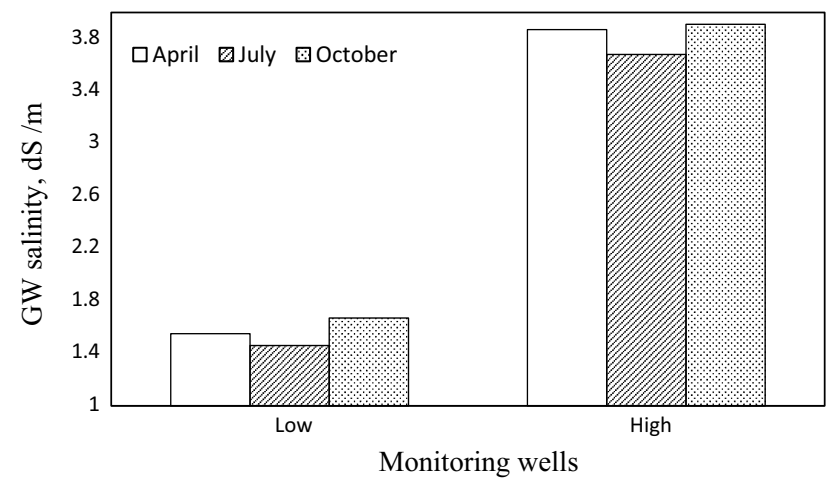

Fig. 7 Average variation of groundwater salinity for low $\left(1.56 \mathrm{dS} \mathrm{m}^{-1}\right)$ and high $\left(3.81 \mathrm{dS} \mathrm{m}^{-1}\right)$ saline categories of observation wells during April, July and October in the Oktepa Zilol Chashmasi WCA, Fergana Valley. The observation wells falling into low and high categories of groundwater salinity are shown in Fig. 6

saline soils were located in the areas of shallow and saline groundwater (Fig. 10).

\section{Establishment of irrigation response units}

Based on the above-described parameters, the final delineation of homogenous IRUs was completed (Fig. 11). The 17 IRUs ranged from shallow and deep groundwater, nonsaline and slightly saline soils, cropping pattern consisting of cotton, winter wheat and vegetables, soil texture and furrow irrigation method (Table 1).

Gross irrigation requirement (GIR) is the volume of water available to the canal command area at the head of canal. This GIR does not include the efficiency within the irrigation network as well as the water losses during the field application. The GIR was calculated for each of the
IRU according to the estimations described in preceding subsections:

$\mathrm{GIR}=\mathrm{CWR}-\mathrm{ER}-\mathrm{GWC}+\mathrm{FAL}+\mathrm{LR}$

where GIR, gross irrigation requirement (mm); CWR, crop water requirements $(\mathrm{mm})$; ER, effective precipitation $(\mathrm{mm})$; GWC, contribution of soil moisture from groundwater $(\mathrm{mm})$; FAL, field application losses $(\mathrm{mm})$; and LR, leaching requirement $(\mathrm{mm})$.

The crop water requirements are defined as the water volumes needed to meet the water loss through evapotranspiration. The crop-specific evapotranspiration $\left(\mathrm{ET}_{\mathrm{c}}\right)$ can be calculated as reference evapotranspiration $\left(\mathrm{ET}_{\mathrm{o}}\right)$ multiplied by the crop coefficients $\left(K_{\mathrm{c}}\right)$ (Allen et al. 1998).

$\mathrm{ET}_{\mathrm{c}}=\mathrm{ET}_{0} \times K_{\mathrm{c}}$

The meteorological data needed for the estimation of $\mathrm{ET}_{\mathrm{o}}$ including minimum and maximum air temperature and relative humidity, wind speed, solar radiation were obtained from the nearby governmental meteorological station "Kuva" for the reference period of 2011-2014. Values of the crop coefficients for the three major crops grown in the Fergana Valley (cotton, winter wheat and vegetables) were obtained from works of the Central Asian Research Institute, Uzbekistan (SANIIRI). Effective precipitation was calculated from the meteorological data using the FAO approach (Brouwer and Heibloem 1986).

Water application efficiencies in different soil textural classes and irrigation methods were taken from Bos (1979, 1980) and Jurriens et al. (2001). Furrow irrigation is virtually the sole method practiced for cotton, vegetables and winter wheat. The loam, sandy loam and silty loam soils of the Oktepa Zilol Chashmasi WCA are typical for the
Fig. 8 Segregated areas with low $\left(1.56 \mathrm{dS} \mathrm{m}^{-1}\right)$ and high $\left(3.81 \mathrm{dS} \mathrm{m}^{-1}\right)$ categories of groundwater salinity in the Oktepa Zilol Chashmasi WCA, Fergana Valley. The observation well numbers (OW) (e.g., OW-162) shown in figure are the official identification tags assigned to each OW by the hydrogeological melioration expedition

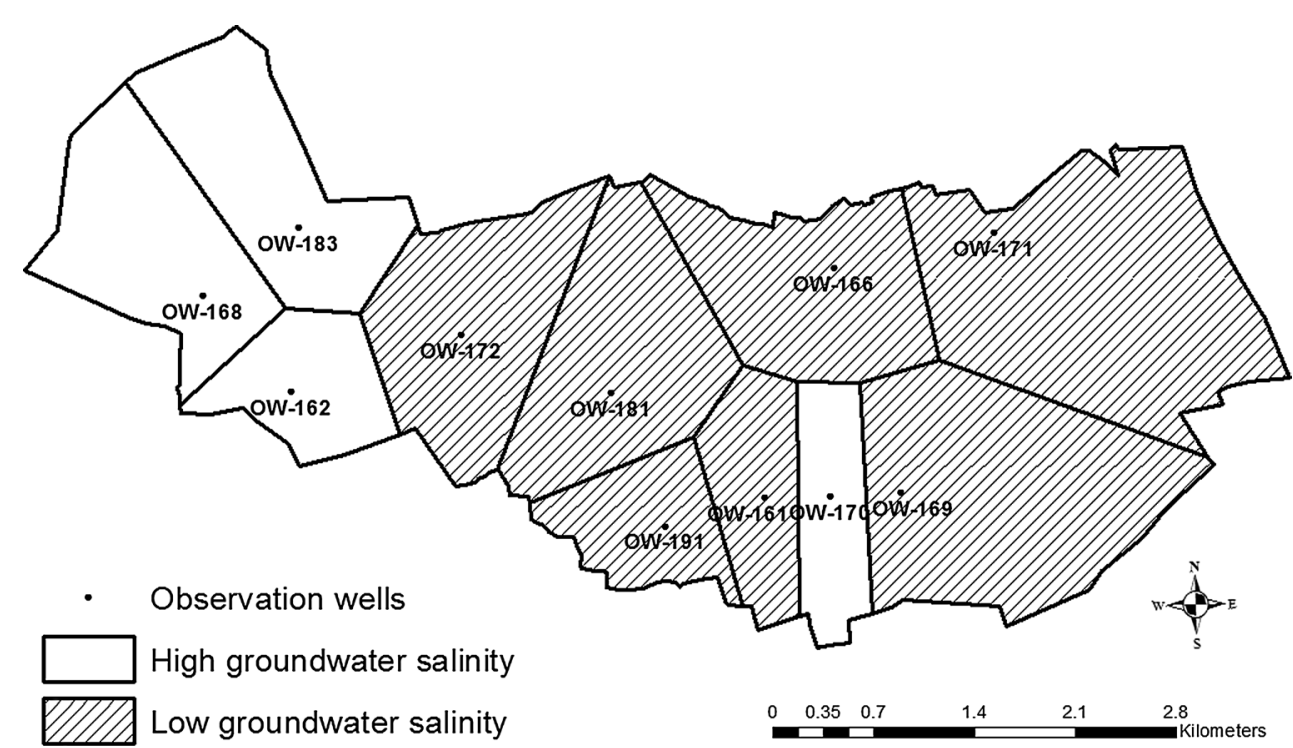


Fig. 9 Field layout for typical cropping patterns in the Oktepa Zilol Chashmasi WCA, Fergana Valley

Fig. 10 Low $\left(3.8 \mathrm{dS} \mathrm{m}^{-1}\right)$ and moderate $\left(6.2 \mathrm{dS} \mathrm{m}^{-1}\right)$ soil salinity in the Oktepa Zilol Chashmasi WCA, Fergana Valley. The salinity values are averaged to a depth of $1 \mathrm{~m}$

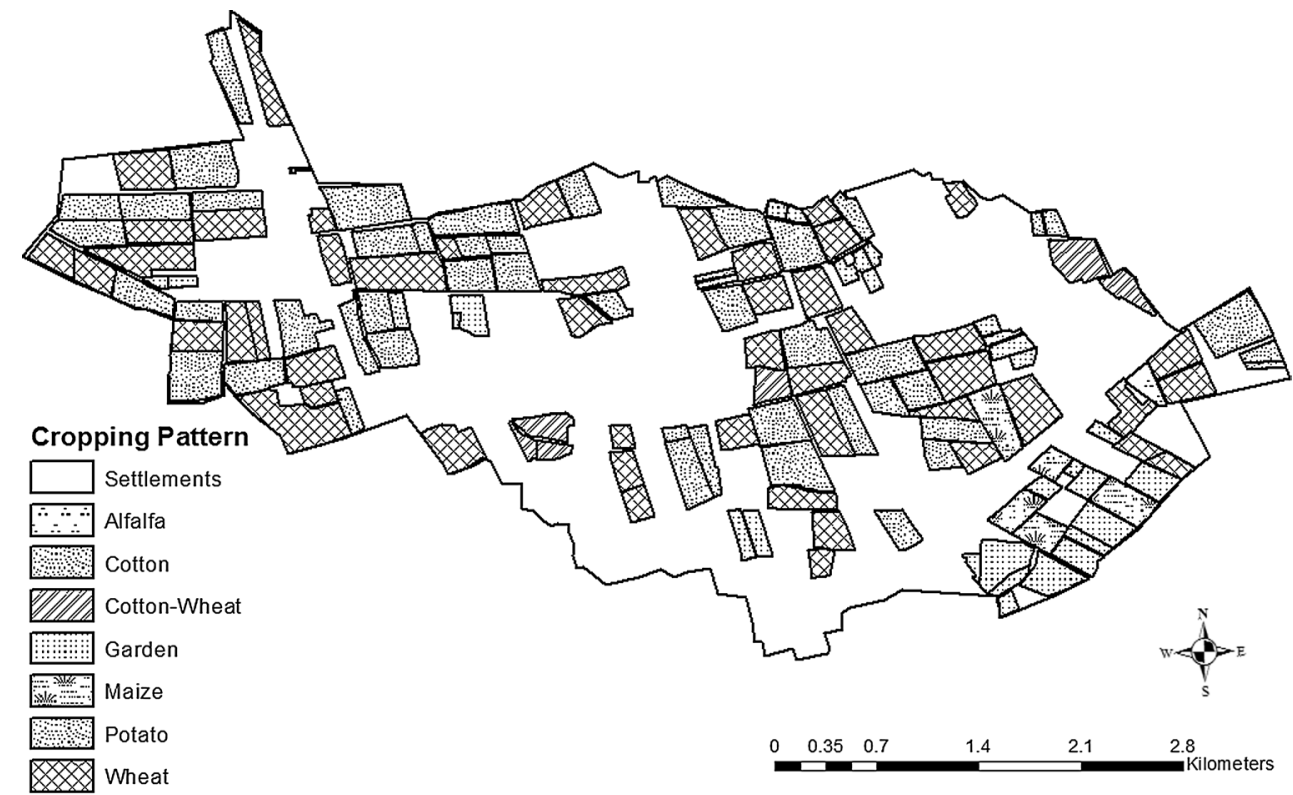

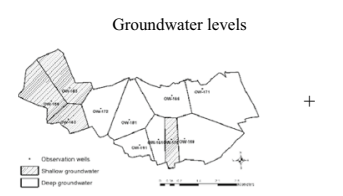
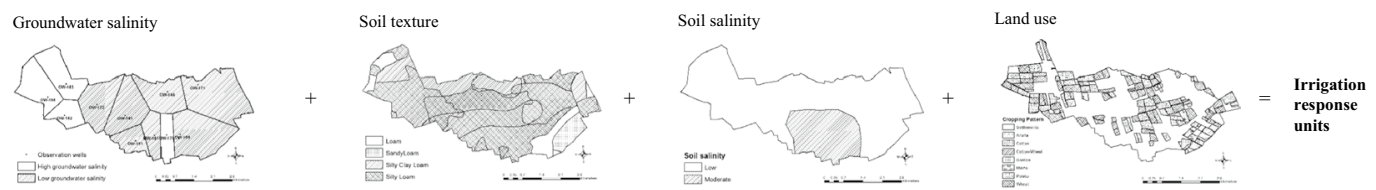

Fig. 11 Scheme of estimation of the irrigation response units, Fergana Valley

region. Groundwater contribution was estimated from previous research (Awan et al. 2014) (cf. Table 1).

Leaching water is applied to the soil surface to generate a downward flow to flush the salts out of the profile, usually applied before the cropping season. The local recommendations are to apply ca. $150 \mathrm{~mm}$ and $600 \mathrm{~mm}$ of water in up to three leaching events depending on salinity levels. In current study, we estimated the leaching requirements using the methodology of Ayers and Westcott (1985). For this estimation, the necessary data on the irrigation water salinity 
Table 1 A review of groundwater contribution under different groundwater (GW) depths, soil texture and cropping patterns

\begin{tabular}{|c|c|c|c|c|}
\hline GW depth (m) & Soil texture & Crop & GW contribution $(\mathrm{mm})$ & Source \\
\hline 0.97 & Sandy loam & Cotton & 194 & Akhtar et al. (2013) \\
\hline 1.2 & Silty loam & Cotton & 153 & Akhtar et al. (2013) \\
\hline 0.81 & Sandy loam & Cotton & 229 & Forkutsa et al. (2009) \\
\hline 0.9 & Sandy loam & Cotton & 77 & As above \\
\hline 0.76 & Sandy loam & Cotton & 49 & As above \\
\hline \multirow[t]{5}{*}{$0.6-1.0$} & Loam & Cotton & 115 & As above \\
\hline & Sandy loam & - & $49-116$ & Kats (1976) \\
\hline & Loam-sandy loam & & $64-115$ & Kvan (1997) \\
\hline & Loam-sandy loam & & $38-48$ & Kharchenko (1975) \\
\hline & Loam-sandy loam & & $204-401$ & $\begin{array}{l}\text { Djurabekov and Laktaev } \\
\text { (1983) }\end{array}$ \\
\hline Shallow GW & Silt loam & Cotton & 164 & Awan et al. (2015) \\
\hline Moderately shallow GW & Silt loam & Cotton & 140 & As above \\
\hline Deep GW & Silt loam & Cotton & 97 & As above \\
\hline Shallow GW & Silt loam & Wheat & 34 & As above \\
\hline Moderately shallow GW & Silt loam & Wheat & 20 & As above \\
\hline Shallow GW & Silt loam & Vegetables & 47 & As above \\
\hline Moderately shallow GW & Silt loam & Vegetables & 20 & As above \\
\hline $1-2$ & & Cotton & 0.6 & Wallender et al. (1979) \\
\hline $1.7-2.1$ & & Cotton & 0.49 & Ayars and Schoneman (1986) \\
\hline 1.5 & & Safflower & 0.4 & Soppe and Ayars (2003) \\
\hline 0.5 & & Wheat & 1 & Kahlown et al. (2005) \\
\hline 0.5 & & Sunflower & 0.8 & Kahlown et al. (2005) \\
\hline
\end{tabular}

Shallow groundwater levels $=<1.5 \mathrm{~m}$, moderately shallow groundwater levels $=1.5-2 \mathrm{~m}$ and deep groundwater levels $=>2$

$\left(\mathrm{EC}_{\mathrm{w}}\right)$ were requested from local water management organization. The salinity tolerance of crops past their germination stages was taken as $7.7 \mathrm{dS} \mathrm{m}^{-1}$ for cotton, $6 \mathrm{dS} \mathrm{m} \mathrm{m}^{-1}$ for winter wheat and $2 \mathrm{dS} \mathrm{m}^{-1}$ for vegetables (Tanji and Kielen 2002). Leaching requirements were then estimated as:

$\mathrm{LR}=\frac{\mathrm{EC}_{\mathrm{w}}}{5\left(\mathrm{EC}_{\mathrm{e}}\right)-\mathrm{EC}_{\mathrm{w}}}, \mathrm{mm}$

where LR is a minimum leaching requirement, mm, needed to control salts within the range of the crop tolerance. $\mathrm{EC}_{\mathrm{w}}$, irrigation water salinity, $\mathrm{dS} \mathrm{m}{ }^{-1} ; \mathrm{EC}_{\mathrm{e}}$, average soil salinity tolerated by crops, $\mathrm{dS} \mathrm{m}^{-1}$.

\section{Results and discussion}

\section{Irrigation response units}

The GIS analysis revealed 17 possible combinations of IRUs in the Oktepa Zilol Chashmasi water consumers association (WCA) (Fig. 12). These IRUs were spread over the territory of the WCA making more than 300 polygons. Each of the polygons is roughly an area that corresponds to the sizes of the agricultural fields in the WCA, which makes it easier for the water managers to estimate water requirements. Analysis of the water productivity in the agricultural areas with similar environmental and management settings (e.g., in the Khorezm region of Uzbekistan, Bekchanov et al. 2010) revealed that splitting the entire region into smaller subareas would ease the estimation of water productivity.

Cotton-wheat, cotton-fallow and vegetables were the most dominant cropping patterns in these IRUs. Groundwater salinity and soil salinity were not major issues in most of the IRUs except for the five IRUs (IRUs 1, 6, 7, 15 and 16), where groundwater salinity was high, and for the two IRUs (14 and 16), where soils were moderately saline. Groundwater depth and soil texture varied among IRUs. These combinations of cropping patterns, largely cotton and wheat, can be found in the Central Asian republics of the former Soviet Union (Abdullaev et al. 2009), while shallow and saline groundwater in most arid flat areas.

\section{Crop evapotranspiration for different irrigation response units}

The crop water requirements differ in the IRUs also because of the specific cropping patterns identified (Table 2). Water requirements of cotton-specific IRUs that occupied the bulk 
Fig. 12 Location of different irrigation response units in the Oktepa Zilol Chashmasi WCA, Fergana Valley

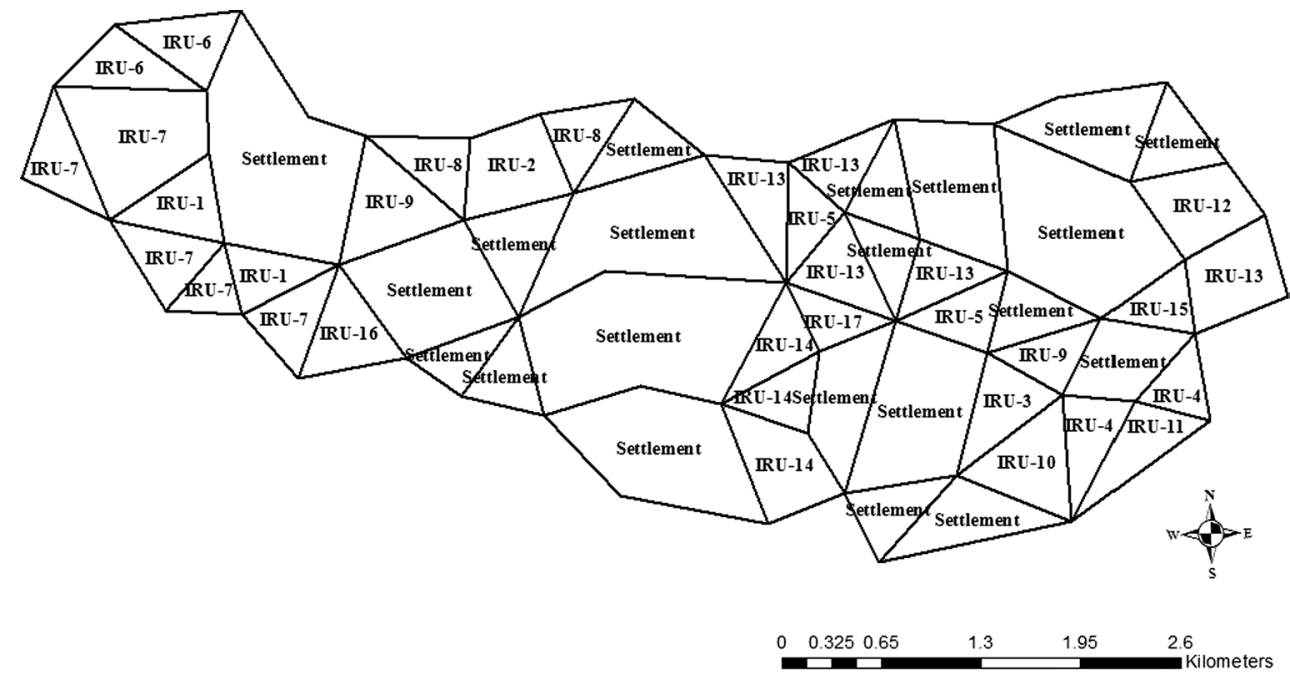

Table 2 Irrigation response units with factors influencing crop water requirements

\begin{tabular}{lllllll}
\hline IRUs & GWS & Soil salinity & Crops & GWL & Soil texture & Irrigation method \\
\hline IRU1 (HLCFDSL) & High & Low & Cotton-fallow & Deep & Silty loam & Furrow-basin \\
IRU2 (LLCFDSCL) & Low & Low & Cotton-fallow & Deep & Silty clay loam & Furrow-basin \\
IRU3 (LLCFDSL) & Low & Low & Cotton-fallow & Deep & Silty loam & Furrow-basin \\
IRU4 (LLCFSSaL) & Low & Low & Cotton-fallow & Shallow & Sandy loam & Furrow-basin \\
IRU5 (LLCFSSL) & Low & Low & Cotton-fallow & Shallow & Silty loam & Furrow-basin \\
IRU6 (HLCWDSCL) & High & Low & Cotton-wheat & Deep & Silty clay loam & Furrow-basin \\
IRU7 (HLCWDSL) & High & Low & Cotton-wheat & Deep & Silty loam & Furrow-basin \\
IRU8 (LLCWDSCL) & Low & Low & Cotton-wheat & Deep & Silty clay loam & Furrow-basin \\
IRU9 (LLCWDSL) & Low & Low & Cotton-wheat & Deep & Silty loam & Furrow-basin \\
IRU10 (LLCWSSL) & Low & Low & Cotton-wheat & Shallow & Loam & Furrow-basin \\
IRU11 (LLWMSSaL) & Low & Low & Wheat-maize & Shallow & Sandy loam & Furrow-basin \\
IRU12 (LLWMSSCL) & Low & Low & Wheat-maize & Shallow & Silty clay loam & Furrow-basin \\
IRU13 (LLWMSSL) & Low & Low & Wheat-maize & Shallow & Silty loam & Furrow-basin \\
IRU14 (LMWMSSL) & Low & Moderate & Wheat-maize & Shallow & Silty loam & Furrow-basin \\
IRU15 (HLVDSL) & High & Low & Vegetables & Deep & Silty loam & Furrow \\
IRU16 (HMVDSL) & High & Moderate & Vegetables & Deep & Silty loam & Furrow \\
\hline
\end{tabular}

Low groundwater salinity $=1.56 \mathrm{dS} \mathrm{m} \mathrm{m}^{-1}$, high groundwater salinity $=3.81 \mathrm{dS} \mathrm{m}^{-1}$, low soil salinity $=3.8 \mathrm{dS} \mathrm{m}^{-1}$, moderate soil salinity $=6.2 \mathrm{dS} \mathrm{m}^{-1}$, shallow groundwater levels $=130-160 \mathrm{~cm}$, deep groundwater levels $=>180 \mathrm{~cm}$

$I R U$ irrigation response units, GWS groundwater salinity, GWL groundwater level of the agricultural areas, gradually increased in the season reaching a peak in July-August and declined from September onwards - the period of harvest. The total water requirements for wheat-cotton IRUs (IRU-6 to IRU-14) amounted to $703 \mathrm{~mm}$ during the study period (Fig. 13). The maximum water requirements occurred during July $(165 \mathrm{~mm})$, which coincided with the period of maximal water demand for cotton. Winter wheat had in general lower water requirements $(471 \mathrm{~mm})$, but for a longer period (October till June) compared to cotton. The period April till July (till May for winter wheat) has the highest probability for water shortages owing to the irrigation needs of all crops and due to the highest water demands. Hence, this period is a most critical for water managers mandated to deliver sufficient water volumes and detrimental for crop production in case of deficiencies. Although vegetables occupy comparatively less acreage, their requirements for irrigation water are only slightly lower compared to those of cotton and wheat $-394 \mathrm{~mm}$ during May till July. The period with lowest water needs is from October till March (except for water for leaching of salinity).

Conrad et al. (2013) used remote sensing techniques to estimate the spatially distributed crop water requirements for the major crops grown in the Fergana Valley of Uzbekistan and derived similar conclusions. 


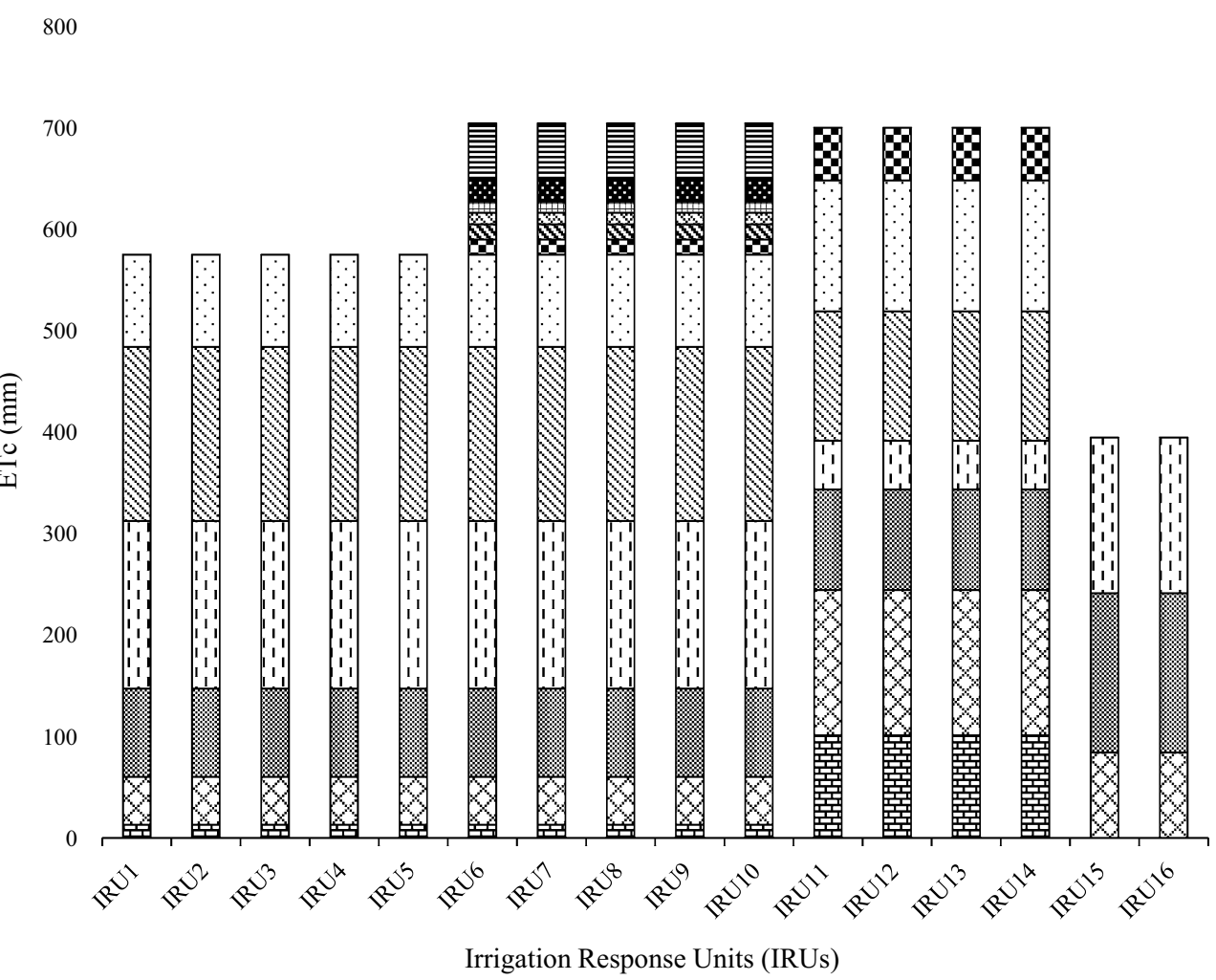

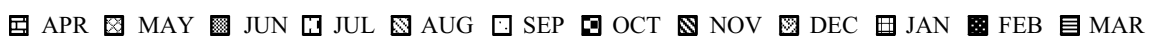

Fig. 13 Annual crop evapotranspiration for different irrigation response units (IRUs)

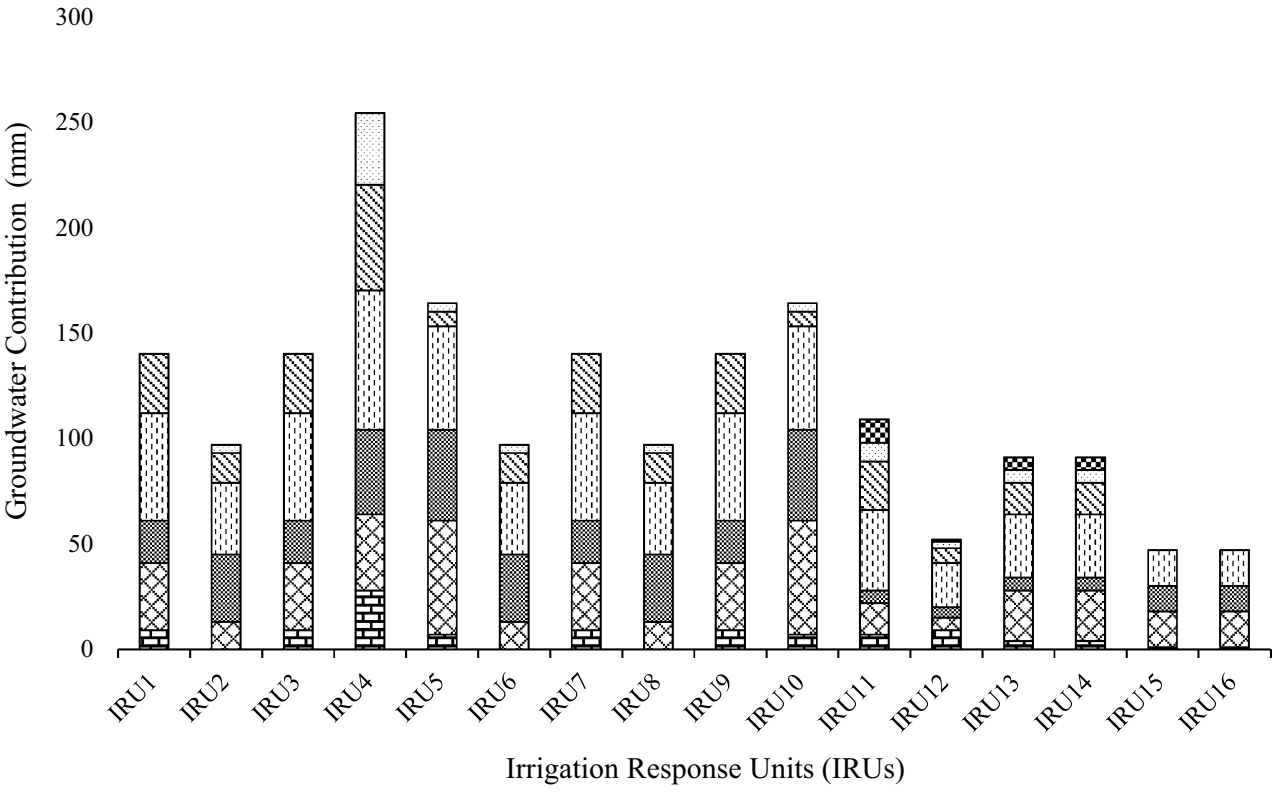

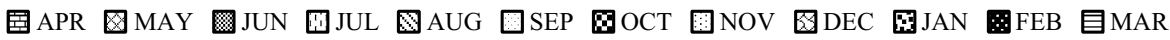

Fig. 14 Annual groundwater contribution for different irrigation response units (IRUs) 
The annual water requirements for cotton-wheat IRUs amounted to $703 \mathrm{~mm}$, which are $18 \%$ more compared to cotton-fallow IRUs and $44 \%$ more compared to vegetable IRUs. These results are close to the estimations in other works (e.g., Conrad et al. 2013).

\section{Groundwater contribution for different irrigation response units}

Groundwater contribution to crop water requirements differed according to IRUs driven by varying groundwater levels, groundwater salinity and cropping pattern (Fig. 14). Maximum groundwater contribution was $254 \mathrm{~mm}$ for IRU-4, which has shallow groundwater levels with good quality, sandy loam soil texture, low soil salinity and cotton-fallow cropping pattern. The minimum groundwater contribution of $47 \mathrm{~mm}$ (IRUs 15 and 16) was dominated by vegetables. The low groundwater contribution in such IRUs is due to in general shallow rooting habits of vegetables (Ayars et al. 2006). The IRUs with cotton-fallow as the major cropping pattern showed on average $150 \mathrm{~mm}$ contributed through the groundwater, whereas cotton-wheat, wheat-maize and vegetables had 128, 86 and $47 \mathrm{~mm}$ groundwater contribution, respectively. The average groundwater contribution for the entire WCA amounted to $117 \mathrm{~mm}$. Cotton, the most dominant crop, profited most from groundwater contribution. A groundwater contribution for cotton-wheat IRUs from December to March did not exist due to low evapotranspiration during the winter season combined with deep groundwater levels due to non-irrigation season. Karimov et al. (2014) used numerical modeling and concluded that the crop water use increases as the depth to groundwater decreases. Promoting groundwater use may serve two important outcomes: lowering excessively shallow groundwater levels and maintaining health and resilience of the soil and water resources (Karimov et al. 2014). However, as pointed by Reddy et al. (2013), farmers with shallow groundwater levels continue applying large irrigation volumes.

The highest groundwater contribution to meeting crop water demands for the entire WCA took place during July. During this month, the evapotranspiration rates, combined with shallow groundwater levels, are high. Wheat relied less on groundwater mainly because of the extremely low water consumption during October until May, when the groundwater levels are comparatively deep. Under shallow groundwater levels (June through August), the groundwater contribution for cultivation of vegetables increases twice and more in the IRUs 4, 5, 10, 11, 12, 13 and 14 (Fig. 14).

\section{Estimation of losses of irrigation water in different Irrigation Response Units}

Due to the water losses in the IRUs with furrow irrigation, additional water supply is required to fulfill the crop

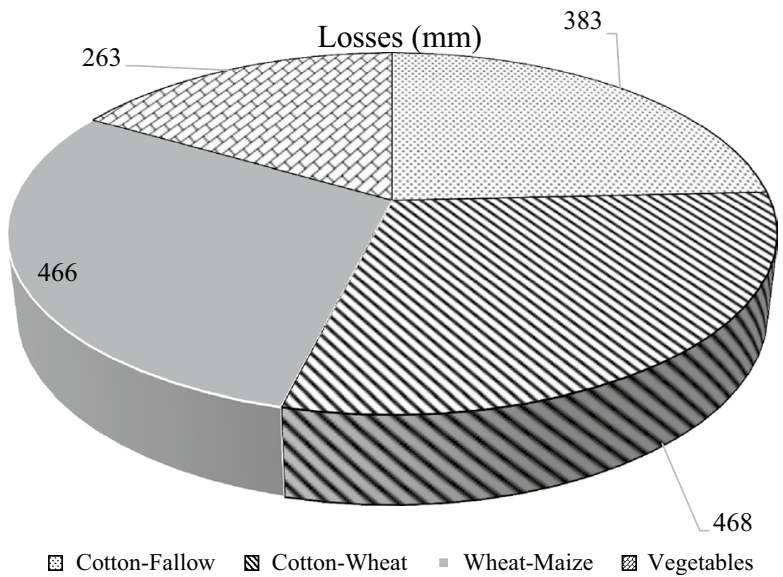

(a)

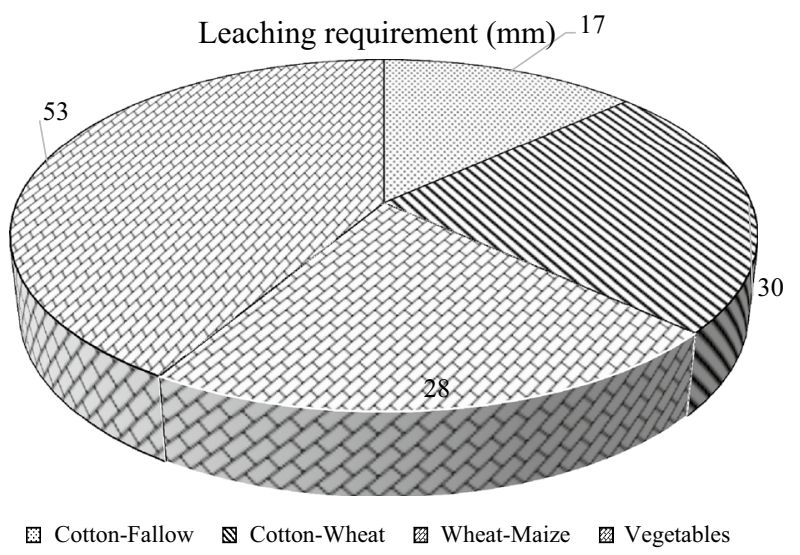

(b)

Fig. 15 Irrigation application losses (a) and leaching requirements (b) for different crop types under different irrigation response units

water requirements, which varies according to the cropping patterns (Fig. 15a). The values for the irrigation water losses were obtained from local research organizations. The highest losses amounted to $468 \mathrm{~mm}$ in wheat-cotton IRUs followed by 466, 383 and $263 \mathrm{~mm}$ for wheat-maize, cotton-fallow and vegetables IRUs, respectively. The average losses for the entire WCA amounted to $415 \mathrm{~mm}$. These values are in line with estimations of Conrad et al. (2013) and indicate a large scope for improvement of the water management in Central Asia. Apparent reasons for heavy water losses are unlined irrigation networks and microtopographic slopes (Reddy et al. 2012) and low field-water application efficiencies.

\section{Leaching requirement for different irrigation response units}

The leaching requirements for IRUs with cotton were relatively low due to a threshold of cotton tolerance to 
soil salinity of $7.7 \mathrm{dS} \mathrm{m}{ }^{-1}$. Hence, the calculated leaching requirements of such IRUs amounted to only $17 \mathrm{~mm}$ (Fig. 15b). The IRUs with wheat as a major crop required more leaching amounts due to the lower threshold salinity value of wheat $\left(6 \mathrm{dS} \mathrm{m}^{-1}\right)$. Therefore, wheat-cotton IRUs have $30 \mathrm{~mm}$, wheat-maize rotation $28 \mathrm{~mm}$, cotton-fallow 17 and vegetables $53 \mathrm{~mm}$ of leaching requirements. It should be noted that despite the generally low sensitivity to salinity, cotton is highly sensitive to salinity during the germination period. Pereira et al. (2009) estimated field percolation losses in the Fergana Valley to range from 140 to $230 \mathrm{~mm}$. These high field losses during the irrigation events are sufficient to leach the salts from the soil root zone.

\section{Gross irrigation requirements for different irrigation response units}

The gross irrigation requirements (GIR) for different IRUs (Fig. 16) varied accordingly. The average irrigation water supply for the entire WCA was $851 \mathrm{~mm}( \pm 143 \mathrm{~mm})$, but the lowest GIR were $629 \mathrm{~mm}$ for IRU-15 and IRU-16. The estimations are in line with those of Conrad et al. (2013) for conditions of the Khorezm province of Uzbekistan. Although the groundwater contribution in both IRUs was minimal, still this did not add to the high surface water requirements due to low crop water requirements in these IRUs. The highest GIR estimated amounted to $1051 \mathrm{~mm}$ in IRU-12. The high GWR for these IRUs is due to only $52 \mathrm{~mm}$ of groundwater contribution. The low groundwater contribution occurred due to silty clay loam soil texture with wheat and maize as cropping patterns.

Estimations show that under the conditions of the largescale irrigation schemes in Central Asia, the crop water requirements are about one-third (32\%) lower than the actual water supplies into the irrigation network, due to low field application ratio $(43 \%)$ and conveyance ratio (76 \%) (Awan et al. 2015). Moreover, farmers tend to over-apply water for irrigation in their anticipation of uncertainty of the water supplies during peak season (Reddy et al. 2013). Despite the much postulated freshwater scarcity of the Central Asian region, enormous water application per ha is a clear indication of the distribution and usage issues rather than physical water scarcity (Rijsberman 2006). The problems of water insufficiency, especially in tail-end parts of the large irrigation systems, are due to water mismanagement (Tischbein et al. 2014). Actual capillary contribution from shallow groundwater accounted for $20 \%$ of the crop water needs, but these effects usually are ignored in the water supply estimations (see also the Awan et al. 2014 in other parts of Uzbekistan).

Intensity of the capillary rise in the local areas with the same depth to groundwater and various soil texture classes differed by $10 \%$, although water supply was the same. The soil salinity of the selected WCA range from non-saline to low saline, and thus, the additional water fractions for leaching requirements should range from none to minimal. In contrast, the leaching fraction was $15 \%$, while huge field-level water losses appeared due to inefficient water application methods. The majority of the crops grown in

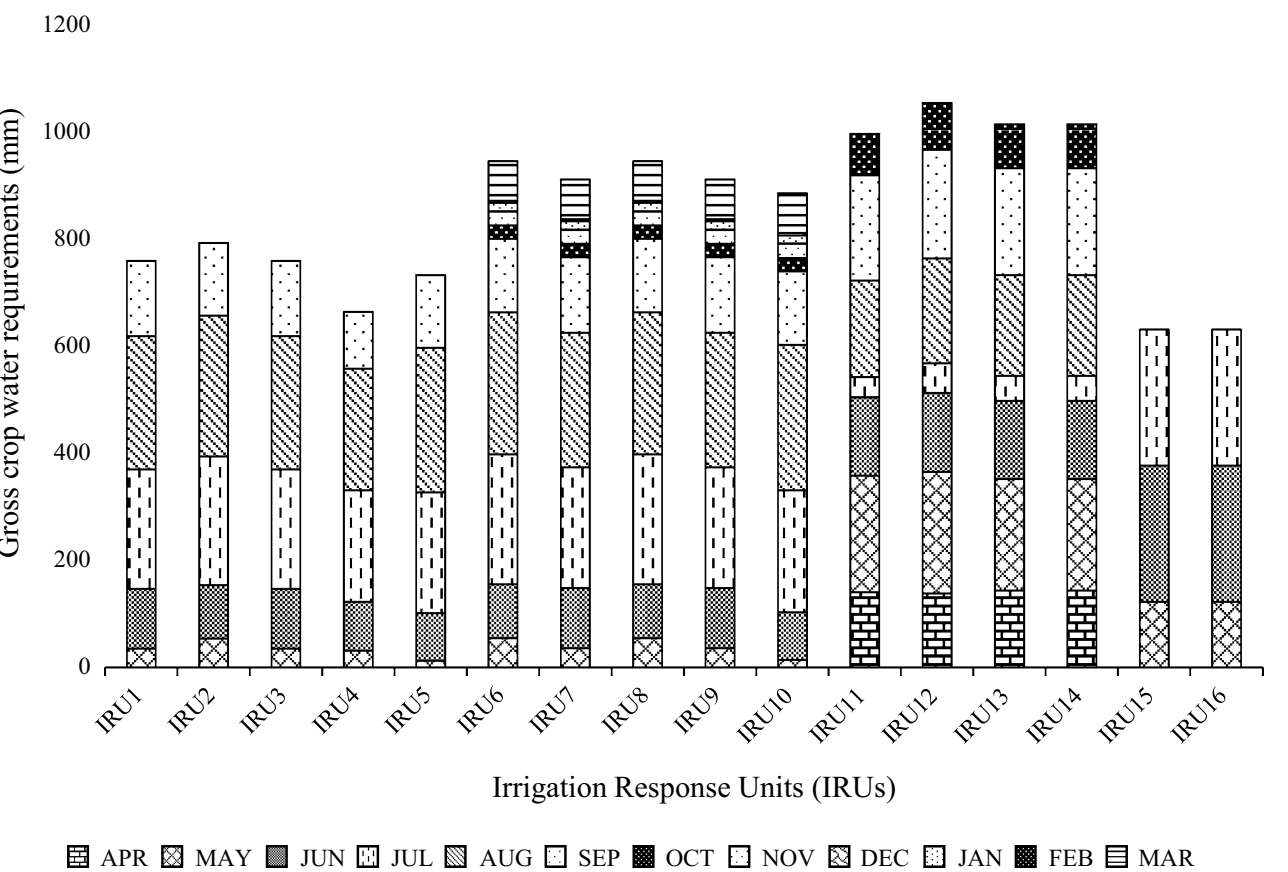

Fig. 16 Monthly gross water requirements for different irrigation response units (IRUs) in the Oktepa Zilol Chashmasi WCA, Fergana Valley 
the region are cotton and winter wheat, followed by vegetables. In spite of the fact that the actual evapotranspiration of wheat is lower than that of cotton, water supply for irrigation of this crop accounted for $75 \%$ of the water supply.

\section{Conclusions}

Irrigation substantially increases agricultural land productivity and so is crucial for food production worldwide. At the same time, intensive and wide-spread land degradation occurs frequently as salinization and waterlogging in arid areas. A major cause of the ongoing degradation is water mismanagement, which in turn is caused also by an improper estimation of crop water requirements. These requirements are estimated based on crop evapotranspiration, while the effects of such factors as soil texture and salinity, groundwater levels and salinity, actual cropping patterns and irrigation methods are not properly accounted for. When accounting concurrently for those factors, impacting actual crop water needs for large-scale irrigation schemes much room for water savings will be disclosed. The methodology of segregating the areas into smaller areal units with similar factors requires, however, further research: to conduct detailed field measurements to support wider-area findings and also to the financial gains that could be made or not when collecting all data needed for identifying IRUs. However, the present findings confirm that smaller areas are much easier to manage, while more precise water saving can lead to better yields and reduced adverse environmental impacts. Practical implementation of this methodology will enable water managers and farmers to better use this valuable resource while preserving the ecological safety.

Acknowledgments The International Center for Agricultural Research in the Dray Areas is in receipt of financial support from the CGIAR Research Program on Water, Land and Ecosystems (WLE), which is used to support this study. The study design, data collection, analysis and interpretation of the results are exclusively those of the authors.

\section{References}

Abdullaev I, de Fraiture C, Giordano M, Yakubov M, Rasulov A (2009) Agricultural water use and trade in Uzbekistan: situation and potential of impacts of market liberalization. Water Resour Dev 25:47-63

Akhtar F, Tischbein B, Awan UK (2013) Optimizing deficit irrigation scheduling under shallow groundwater conditions in lower reaches of Amu Darya River Basin. Water Resour Manage 27(8):3165-3178

Ali MH (2010) Fundamentals of irrigation and on-farm water management, vol 1. Springer, New York. doi:10.1007/978-1-4419-6335-2.9

Allen RG, Pereira LS, Raes D, Smith M (1998) Crop evapotranspiration-guidelines for computing crop water requirements-FAO irrigation and drainage paper 56. FAO, Rome
Arnold JG, Srinivasan R, Muttiah RS, Williams JR (1998) Large area hydrologic modeling and assessment. Part I: model development. J Am Water Resour Assoc 34(1):73-89

Aslam M, Prathapar SA (2006) Strategies to mitigate secondary salinization in the Indus Basin of Pakistan: a selective review. Research Report 97. International Water Management Institute (IWMI), Colombo

Awan UK, Ibrakhimov M, Tischbein B, Kamalov P, Martius C, Lamers JPA (2011) Improving irrigation water operation in the lower reaches of the Amu Darya River-current status and suggestions. Irrig Drain J 60(5):600-612

Awan UK, Tischbein B, Martius C (2014) A GIS-based approach for up-scaling capillary rise from field to system level under soilcrop-groundwater mix. Irrig Sci 32(6):449-458

Awan UK, Tischbein B, Martius C (2015) Simulating groundwater dynamics using FEFLOW-3D groundwater model under complex irrigation and drainage network of dryland ecosystems of central Asia. Irrig Drain 46:283-296

Ayars JE, Christen EW, Soppe RW, Meyer WS (2006) The resource potential of in situ shallow ground water use in irrigated agriculture: a review. Irrig Sci 24(3):147-160

Ayars JE, Schoneman RA (1986) Use of saline water from a shallow water table by cotton. Trans ASAE 29(6):1674-1678

Ayers RS, Westcott DW (1985) Water quality for agriculture. FAO Irrigation and Drainage Paper No. 29. FAO Rome, 19

Bekchanov M, Karimov A, Lamers JPA (2010) Impact of water availability on land and water productivity: a temporal and spatial analysis of the case study region Khorezm, Uzbekistan. Water 2:668-684. doi:10.3390/w2030668

Bos MG (1979) Standards for irrigation efficiency of the ICID. J Irrig Drain Div ASCE 105:37-43

Bos MG (1980) Irrigation efficiencies at crop production level. ICID Bull 29(2):18-26

Brouwer C, Heibloem M (1986) Irrigation water management: irrigation water needs. FAO, Training manual no. 3, Rome

Cai XM, Rosegrant MW, Ringler C (2003) Physical and economic efficiency of water use in the river basin: implications for efficient water management-art. no. 1013. Water Resour Res 39(1): 1013

Chen X, Hu Q (2004) Groundwater influences on soil moisture and surface evaporation. J Hydrol 297(1-4):285-300

Conrad C, Rahmann M, Machwitz M, Stulina G, Paeth H, Dech S (2013) Satellite based calculation of spatially distributed crop water requirements for cotton and wheat cultivation in Fergana Valley, Uzbekistan. Glob Planet Change A 110:88-98. doi:10.1016/j.gloplacha.2013.08.002

Djurabekov IH, Laktaev NT (1983) Improvement of irrigation systems and soil amelioration in Uzbekistan. Uzbekistan, Tashkent (In Russian)

Forkutsa I, Sommer R, Shirokova YI, Lamers JPA, Kienzler K, Tischbein B, Martius C, Vlek PLG (2009) Modeling irrigated cotton with shallow groundwater in the Aral Sea Basin of Uzbekistan: I. water dynamics. Irrig Sci 27(4):331-346

Hillel D (2000) Salinity management for sustainable irrigation: integrating science, environment and economics. World Bank, Washington

Ibrakhimov M, Martius C, Lamers JPA, Tischbein B (2011) The dynamics of groundwater table and salinity over 17 years in Khorezm. Agric Water Manag 101(1):52-61

Jalili S, Moazed H, Boroomand NS, Naseri AA (2011) Assessment of evaporation and salt accumulation in bare soil: constant shallow water table depth with saline ground water. Sci Res Essays 6(29):6068-6074. doi:10.5897/SRE11.509

Jurriens M, Zerihun D, Boonstra J, Feyen J (2001) SURDEV: surface irrigation software. International Institute for Land Reclamation and Improvement, Wageningen 
Kahlown MA, Ashraf M, Zia-ul-Haq (2005) Effect of shallow groundwater table on crop water requirements and crop yields. Agric Water Manag 76(1):24-35

Karimov AK, Šimůnek J, Hanjra MA, Avliyakulov M, Forkutsa I (2014) Effects of the shallow water table on water use of winter wheat and ecosystem health: implications for unlocking the potential of groundwater in the Fergana Valley (Central Asia). Agric Water Manag 131:57-69

Kats DM(1976) Influence of irrigation on the groundwater table. Kolos Publishers, Moscow (In Russian)

Kharchenko SI (1975) Hydrology of irrigated lands. Gidrometeoizdat, Leningrad, p 374 (In Russian)

Kvan RA (1997) The main concepts and peculiarities of methods used in Kazakhstan to calculate crop water use, irrigation regime and irrigation scheduling (In Russian)

Lehmann P, Assouline S, Or D (2008) Characteristic lengths affecting evaporative drying of porous media. Phys Rev E 77:056309

Li X, Liu Y, Chen M, Song YP, Song J, Wang BS et al (2012) Relationships between ion and chlorophyll accumulation in seeds and adaptation to saline environments in Suaeda salsa populations. Plant Biosyst 146:142-149

Liaqat UW, Choi M, Awan UK (2015) Spatio-temporal distribution of actual evapotranspiration in the Indus basin irrigation system. Hydrol Process 29(11):2613-2627

Martius C, Lamers JPA, Wehrheim P, Schoeller-Schletter A, Eshchanov R, Tupitsa A, Khamzina A, Akramkhanov A, Vlek PLG (2004) Developing sustainable land and water management for the Aral Sea Basin through an interdisciplinary research. In: Seng V, Craswell E, Fukai S (eds) Water in agriculture. Australian Centre for International Agricultural Research (ACIAR) Proceedings No 116, Canberra, pp 45-60

Nulsen RA (1981) Critical depth to saline groundwater in non-irrigated situations. Aust J Soil Res 19(1):83-86. doi:10.1071/ SR9810083

Pereira LS, Paredes P, Cholpankulov ED, Inchenkova OP, Teodoro PR, Horst MG (2009) Irrigation scheduling strategies for cotton to cope with water scarcity in the Fergana Valley, Central Asia. Agric Water Manag 96(5):723-735. doi:10.1016/j. agwat.2008.10.013

Postel S (2001) Growing more food with less water. Sci Am 284(2):46-51

Rasheed HR, Al-Anaz H, Abid KA (1989) Evaporation from soil surface in presence of shallow water tables. In: Proceedings of the Baltimore symposium, Baltimore, Maryland. IAHS Publ. no. 181

Reddy JM, Muhammedjanov S, Jumaboev K, Eshmuratov D (2012) Analysis of cotton water productivity in Fergana Valley of Central Asia. Agric Sci 3(6):822-834

Reddy JM, Jumaboev K, Matyakubov B, Eshmuratov D (2013) Evaluation of furrow irrigation practices in Fergana Valley of Uzbekistan. Agric Water Manag 117:133-144
Rhoades JD, Kandiah Mashali AM (1992) The use of saline waters for crop production. FAO Irrigation and Drainage Paper No. 48. Rome

Rijsberman FR (2006) Water scarcity: Fact or fiction? Agricultural Water Management, Special Issue on Water scarcity: challenges and opportunities for crop science, vol 80 , issues $1-3,24$, pp $5-22$

Scanlon BR, Keese KE, Flint AL, Flint LE, Gaye CB, Edmunds WM, Simmers I (2006) Global synthesis of groundwater recharge in semiarid and arid regions. Hydrol Process 20(15):3335-3370

Shah N, Nachabe M, Ross M (2007) Extinction depth and evapotranspiration from groundwater under selected land covers. Ground Water 45(3):329-338

Shokri N, Salvucci GD (2011) Evaporation from porous media in the presence of a water table. Vadose Zone J 10(4):1309-1318

Singh NT (2005) Irrigation and soil salinity in the Indian subcontinent: past and present. Lehigh University Press, Bethlehem

Soppe RWO, Ayars JE (2003) Characterizing ground water use by safflower using weighing lysimeters. Agric Water Manag 60(1):59-71

Tanji K, Kielen NC (2002) Agricultural drainage water management in arid and semi-arid areas. In: FAO irrigation and drainage paper no. 61. Food and Agriculture Organization, Rome

Tischbein B, Awan UK, Akhtar F, Kamalov P, Manschadi AM (2014) Improving irrigation efficiency in the lower reaches of the Amu Darya River. In: Lamers JPA, Khamzina A, Rudenko I, Vlek PLG (eds) Restructuring land allocation, water use and agricultural value chains. Technologies, policies and practices for the lower Amudarya region, 1st edn. Bonn University Press, V\&R Unipress, Göttingen, pp 91-108. doi:10.14220/9783737002974.91

Tyagi NK (1997) 1996. Salinity management: the CSSRI experience and future research agenda. In: Snellen WB (ed) Towards integration of irrigation and drainage management. ILRI, Wageningen, pp 17-27

United Nations Educational, Scientific and Cultural Organization (2015) Water for a sustainable world, report by The United Nations World Water Development

Varis O (2014) Comment: curb vast water use in central Asia. Nature 514:27-29

Wallender WW, Grimes DW, Henderson DW, Stromberg LK (1979) Estimating the contribution of a perched water table to the seasonal evapotranspiration of Cotton1. Agron J 71(6): 1056

Wilson GW (1990) Soil evaporative fluxes for geotechnical engineering problems. Ph.D. thesis, Department of Civil Engineering, University of Saskatchewan, Saskatoon, SK

Wösten JHM, Pachepsky YA, Rawls WJ (2001) Pedotransfer functions: bridging the gap between available basic soil data and missing soil hydraulic characteristics. J Hydrol 251(3-4):123-150 